\title{
The Development and Trends Of China's Intangible Cultural Heritage Representative List $^{1}$
}

\author{
YE Peng \\ School of information management, \\ Wuhan University \\ Wuhan, China
}

\author{
ZHOU Yao-lin \\ School of information management, \\ Wuhan University \\ Wuhan, China
}

\begin{abstract}
Paper expounds the Chinese intangible cultural heritage list system by quantitative statistics and data analysis. According to analyze data and current problems of Chinese intangible cultural heritage list, it puts forward development trends and way to solving problems.
\end{abstract}

Keywords-China; development; trends; intangible cultural heritage; list

\section{INTRODUCTION}

The UNESCO announced "human oral and non-material heritage representative work list" on May 18, 2001. It pushed the governments paid more attention to protect national intangible cultural heritage in the world. In October 2003, the 32nd session of the UNESCO conference through the convention on the protection of intangible cultural heritage, explicitly proposed "the human intangible cultural heritage representative work list" and "urgently needs to protect the intangible cultural heritage list" for the construction of the rules. As one of the contracting parties, the government of China promised to protect and inherit the outstanding human culture, promoted the sustainable development of human society from the aspects of social, economic and legal environment.

So far, the 217 projects from about 140 countries were listed in the human intangible cultural heritage representative work list, 27 projects from 16 countries were listed in the need to protect the intangible cultural heritage list. Among them, 29 projects in China were listed as human intangible cultural heritage representative work list, such as the Chinese Dragon Boat Festival, Chinese calligraphy, paper cutting, the traditional wooden construction techniques. 7 projects in China were listed as the need to protect the non-material cultural heritage list, such as spun silk embroideries tradition of $\mathrm{Li}$ nationality, Chinese traditional wooden arch bridge construction techniques.

Nowadays, China has become the most populous nation in the world human intangible cultural heritage representative work list.

\section{THE DEVELOPING COURSE OF CHINESE INTANGIBLE CUltural HERITAGE REPRESENTATIVE LIST}

In the early 1950's, the Chinese government organized departments and experts to investigate the minority cultural heritages in China, then taken measures to protect and nurture a large number of traditional arts and crafts industry. The government named 200 people as the national arts and crafts masters [1]. This was the beginning of the heritage protection in China.

In 1979, Ministry of culture, State ethnic affairs commission, China federation of literary and art circles had jointly initiated compilation work of "China national folk literature and art books", More than 30 years, hundreds of cultural workers participated in writing the series books. In 2010, the ten sets of books were completed and contained 298 volumes of 395 of the 450 million words in total [2].

In 2003, State ethnic affairs commission, Ministry of culture, Ministry of finance, and China federation of literary and art circles had jointly launched the Chinese national folk culture protection project. The project plan cost 17 years. By 2020, China will preliminarily establish a relatively complete intangible cultural heritage protection system.

In 2004, Ministry of culture, Ministry of finance had jointly issued "Chinese folk culture protection plan". It was the first time to draw up a plan for establishing a national folk culture protection list.

In 2006, the state council of China had issued a decree which name was "The first batch of national level intangible cultural heritage list". It marked the first batch of national level intangible cultural heritage project formally established, which involving 758 units to be protected, covers 518 national catalogue.

In 2007, China had carried out the first intangible cultural heritage census all over the country. The work was a scientific, comprehensive, systematic foundation for Chinese national intangible cultural heritage system.

In 2008, Chinese intangible cultural heritage protection had made a breakthrough. The "Level 4 protection list system" has been gradually established. At the same year, the government also set up the "Intangible cultural heritage inheritance person protection system" and effectively promoted the "Cultural heritage awareness day".

In 2009, the CPC central committee and the state council of China had jointly issued a number of important documents, which established principles and tasks about intangible cultural heritage protection works in China. The documents determined the "Level 4 protection list system", which included national level, provincial level, city level and country level. The system included naming, awarding, commendation, reward and others ways for protecting intangible cultural heritage and representative inheritance persons in China.

In 2010, the first intangible cultural heritage census was over. The census cost about 800 million CNY and held more 
than 71,000 times symposiums, visited more than 1.15 million folk artists, collected about 290,000 projects of precious objects and information, written 9.96 million words of census, made 234,000 hours audio records, 183,000 hours video records, 4.774 million pieces of camera shootings, more than 142,000 copies of compiled census data. The first intangible cultural heritage census counted more than 970,000 projects of intangible cultural heritage in China [3].

In 2011, "The intangible cultural heritage law" was enacted in China. It put forward normative requirements of intangible cultural heritage protection as three aspects, which include survey system, directory system and transmission system. The law especially specified intangible cultural heritage representative projects in the chapter 3 . It marked that Chinese intangible cultural heritage protection took to a legal orbit.

In 2012, four provinces in China have been released the 4th batch of provincial level intangible cultural heritage protection list.

\section{THE DEVELOPMENT EFFORTS OF CHINESE}

INTANGIBLE CUltural HERITAGE REPRESENTATIVE LIST

\section{A. projects Lists}

Ministry of culture established the national level intangible cultural heritage representative list which must be from the provincial level. And the provincial intangible cultural heritage representative list must be from city level or country level.

In 2006, 2008 and 2011, the state council announced three batches of national level intangible cultural heritage list, a total of 1,219 projects(Table I ). The system of national, provincial, city and county level list has been basically formed. From total view, Chinese governments at all levels have issued 8,786 provincial intangible cultural heritage project(Table II ), 18,186 city level intangible cultural heritage projects and 53,776 county level intangible cultural heritage project [4].

For the current data of Chinese intangible cultural heritage projects, there have been more than 70,000 projects in the 4 level intangible cultural heritage protection systems [5]. But it only occupied $7 \%$ in the total 970,000 projects of Chinese intangible cultural heritage resources. From these data, we can know the Chinese intangible cultural heritage resources have a large exploring space and a serious protection pressure.

TABLE I. The NATINAL LeVEl of Chinese InTANGIBLE Cultural HERITAGE PROJECTS

\begin{tabular}{|l|c|c|c|c|}
\hline \multicolumn{1}{|c|}{ Element } & $\begin{array}{c}\text { The 1st } \\
\text { batch }\end{array}$ & $\begin{array}{c}\text { The 2nd } \\
\text { batch }\end{array}$ & $\begin{array}{c}\text { The 3rd } \\
\text { batch }\end{array}$ & $\begin{array}{c}\text { The 4th } \\
\text { batch }\end{array}$ \\
\hline Folk literature & 31 & 53 & 41 & 125 \\
\hline The traditional music & 72 & 67 & 16 & 155 \\
\hline Traditional dance & 41 & 55 & 15 & 111 \\
\hline Traditional operas & 92 & 46 & 20 & 158 \\
\hline Traditional art & 51 & 45 & 13 & 109 \\
\hline Traditional skills & 89 & 97 & 26 & 212 \\
\hline Traditional medicine & 9 & 8 & 4 & 21 \\
\hline shuochang & 46 & 50 & 18 & 114 \\
\hline Folk customs & 70 & 51 & 23 & 144 \\
\hline
\end{tabular}

\begin{tabular}{|c|c|c|c|c|}
\hline Element & $\begin{array}{c}\text { The 1st } \\
\text { batch }\end{array}$ & $\begin{array}{c}\text { The 2nd } \\
\text { batch }\end{array}$ & $\begin{array}{c}\text { The 3rd } \\
\text { batch }\end{array}$ & $\begin{array}{c}\text { The 4th } \\
\text { batch }\end{array}$ \\
\hline $\begin{array}{l}\text { Traditional sports, } \\
\text { recreational and } \\
\text { acrobatics }\end{array}$ & 17 & 38 & 15 & 70 \\
\hline Total & 518 & 510 & 191 & 1219 \\
\hline
\end{tabular}

TABLE II. THE PROVINCIAL LEVEL OF CHINESE INTANGIBLE Cultural heritage Projects

\begin{tabular}{|c|c|c|c|c|c|c|}
\hline Rank & Province & $\begin{array}{l}\text { The } \\
\text { 1st } \\
\text { batch }\end{array}$ & $\begin{array}{l}\text { The } \\
\text { 2nd } \\
\text { batch }\end{array}$ & $\begin{array}{l}\text { The } \\
\text { 3rd } \\
\text { batch }\end{array}$ & $\begin{array}{l}\text { The } \\
\text { 4th } \\
\text { batch }\end{array}$ & Total \\
\hline 1 & Zhejiang province & 64 & 225 & 246 & 202 & 737 \\
\hline 2 & Hebei province & 130 & 97 & 139 & 111 & 477 \\
\hline 3 & Guizhou province & 91 & 202 & 147 & 1 & 440 \\
\hline 4 & Sichuan province & 189 & 137 & 89 & 1 & 415 \\
\hline 5 & Henan province & 148 & 129 & 95 & I & 372 \\
\hline 6 & Jiangxi province & 62 & 102 & 206 & / & 370 \\
\hline 7 & Shaanxi province & 145 & 100 & 116 & l & 361 \\
\hline 8 & $\begin{array}{l}\text { Guangdong } \\
\text { province }\end{array}$ & 78 & 104 & 123 & 52 & 357 \\
\hline 9 & Fujian province & 101 & 98 & 82 & 73 & 354 \\
\hline 10 & Shanxi Province & 105 & 141 & 82 & I & 328 \\
\hline 11 & $\begin{array}{l}\text { The Tibet } \\
\text { autonomous } \\
\text { region }\end{array}$ & 38 & 83 & 101 & 101 & 323 \\
\hline 12 & $\begin{array}{l}\text { Shandong } \\
\text { province }\end{array}$ & 157 & 150 & / & / & 307 \\
\hline 13 & $\begin{array}{l}\text { The guangxi } \\
\text { zhuang } \\
\text { autonomous } \\
\text { region }\end{array}$ & 58 & 63 & 86 & 98 & 305 \\
\hline 14 & $\begin{array}{l}\text { Inner Mongolia } \\
\text { autonomous } \\
\text { region }\end{array}$ & 140 & 111 & 48 & / & 299 \\
\hline 15 & Jiangsu province & 123 & 112 & 63 & l & 298 \\
\hline 16 & Chongqing city & 62 & 97 & 119 & l & 278 \\
\hline 17 & Yunnan province & 147 & 124 & I & I & 271 \\
\hline 18 & Gansu province & 85 & 88 & 91 & 1 & 264 \\
\hline 19 & Anhui province & 83 & 90 & 81 & l & 254 \\
\hline 20 & Hubei province & 97 & 66 & 90 & 1 & 253 \\
\hline 21 & $\begin{array}{l}\text { The xinjiang } \\
\text { uygur } \\
\text { autonomous } \\
\text { region }\end{array}$ & 108 & 77 & 52 & / & 237 \\
\hline 22 & Beijing city & 48 & 105 & 59 & / & 212 \\
\hline 23 & Hunan province & 74 & 84 & 50 & 1 & 208 \\
\hline 24 & Liaoning province & 60 & 54 & 41 & 35 & 190 \\
\hline 25 & $\begin{array}{l}\text { Heilongjiang } \\
\text { province }\end{array}$ & 57 & 79 & 47 & I & 183 \\
\hline 26 & Jilin province & 75 & 105 & / & l & 180 \\
\hline 27 & Shanghai city & 83 & 45 & 29 & I & 157 \\
\hline 28 & Qinghai province & 33 & 69 & 48 & I & 150 \\
\hline 29 & Tianjin city & 30 & 50 & 1 & 1 & 80 \\
\hline 30 & Hainan province & 1 & 1 & 1 & 72 & 72 \\
\hline 31 & $\begin{array}{l}\text { The ningxia hui } \\
\text { autonomous } \\
\text { region }\end{array}$ & 31 & 23 & I & / & 54 \\
\hline 32 & Taiwan province & 1 & 1 & 1 & 1 & 1 \\
\hline 33 & $\begin{array}{l}\text { The Hong Kong } \\
\text { special } \\
\text { administrative } \\
\text { region }\end{array}$ & / & / & / & / & / \\
\hline 34 & $\begin{array}{l}\text { The Macao } \\
\text { special } \\
\text { administrative } \\
\text { region }\end{array}$ & / & l & l & / & / \\
\hline \multicolumn{2}{|r|}{ Total } & 2774 & 3010 & 2330 & 672 & 8786 \\
\hline
\end{tabular}

According to the provincial and city governments published data sorting 


\section{B. Representative Inheritance Person Lists}

To strengthen the protection of representative inheritance person, the ministry of culture named four batches national level representative inheritance person lists which included 1986 people(Table III ). And the provincial level representative inheritance person lists also contained 9,564 people. Since 2008, the central government has appropriated 8,000 CNY per person per year for supporting inheritance person to inherit intangible cultural heritage. Since 2011, the subsidy standards have been improved to $10,000 \mathrm{CNY}$ per person per year [6].

TABLE III. The Four Batches NATIONAL LEVEL OF Chinese REPRESENTATIVE INHERITANCE PERSONS

\begin{tabular}{|l|c|c|c|c|c|c|}
\hline \multicolumn{1}{|c|}{ Element } & $\begin{array}{c}\text { The } \\
\text { 1st } \\
\text { batch }\end{array}$ & $\begin{array}{c}\text { The } \\
\text { 2nd } \\
\text { batch }\end{array}$ & $\begin{array}{c}\text { The } \\
\text { 3rd } \\
\text { batch }\end{array}$ & $\begin{array}{c}\text { The } \\
\text { 4th } \\
\text { batch }\end{array}$ & Total & Proportion \\
\hline $\begin{array}{l}\text { Folk } \\
\text { literature }\end{array}$ & 32 & $/$ & 25 & 20 & 77 & $3.8 \%$ \\
\hline $\begin{array}{l}\text { The } \\
\text { traditional } \\
\text { music }\end{array}$ & $/$ & 104 & 96 & 31 & 231 & $11.7 \%$ \\
\hline $\begin{array}{l}\text { Traditional } \\
\text { dance }\end{array}$ & $/$ & 72 & 56 & 49 & 177 & $8.9 \%$ \\
\hline $\begin{array}{l}\text { Traditional } \\
\text { operas }\end{array}$ & $/$ & 304 & 196 & 111 & 611 & $30.8 \%$ \\
\hline $\begin{array}{l}\text { Traditional } \\
\text { art }\end{array}$ & 72 & $/$ & 83 & 76 & 231 & $11.7 \%$ \\
\hline $\begin{array}{l}\text { Traditional } \\
\text { skills }\end{array}$ & 78 & $/$ & 136 & 112 & 326 & $16.4 \%$ \\
\hline $\begin{array}{l}\text { Traditional } \\
\text { medicine }\end{array}$ & 29 & $/$ & 24 & 21 & 74 & $3.7 \%$ \\
\hline shuochang & $/$ & 66 & 51 & 34 & 151 & $7.6 \%$ \\
\hline $\begin{array}{l}\text { Folk } \\
\text { customs }\end{array}$ & $/$ & 5 & 25 & 31 & 61 & $3.0 \%$ \\
\hline $\begin{array}{l}\text { Traditional } \\
\text { sports, } \\
\text { recreational } \\
\text { and } \\
\text { acrobatics }\end{array}$ & 15 & $/$ & 19 & 13 & 47 & $2.4 \%$ \\
\hline \begin{tabular}{c} 
Total \\
\hline
\end{tabular} & 226 & 551 & 711 & 498 & 1986 & $100 \%$ \\
\hline
\end{tabular}

Through the Chinese national level representative inheritance person lists and data analysis, this paper can get the following conclusions.

1) The age structure was obvious too old(Table $I V)$ : $63.2 \%$ of people distributed form 60 to 90 years old (19201949). Considering the intangible cultural heritage skills need 5-8 years to full inheritance, the government must increasing investment and training speed to reverse the adverse situation of intangible cultural heritage skills.

TABLE IV. The Age Structure Statistical Tables of National LEVEL OF CHINESE REPRESENTATIVE INHERITANCE PERSONS

\begin{tabular}{|c|c|c|c|c|c|c|}
\hline $\begin{array}{l}\text { Age } \\
\text { Group }\end{array}$ & $\begin{array}{l}\text { The } \\
\text { 1st } \\
\text { batch }\end{array}$ & $\begin{array}{l}\text { The } \\
\text { 2nd } \\
\text { batch }\end{array}$ & $\begin{array}{c}\text { The } \\
\text { 3rd } \\
\text { batch }\end{array}$ & $\begin{array}{l}\text { The } \\
\text { 4th } \\
\text { batch }\end{array}$ & Total & Proportion \\
\hline $\begin{array}{l}\text { And } \\
\text { before } \\
1909\end{array}$ & 0 & 1 & 1 & 0 & 2 & $0.1 \%$ \\
\hline $\begin{array}{l}1910- \\
1919\end{array}$ & 3 & 7 & 2 & 0 & 12 & $0.6 \%$ \\
\hline
\end{tabular}

\begin{tabular}{|l|c|c|c|c|c|c|}
\hline $\begin{array}{c}\text { Age } \\
\text { Group }\end{array}$ & $\begin{array}{c}\text { The } \\
\text { 1st } \\
\text { batch }\end{array}$ & $\begin{array}{c}\text { The } \\
\text { 2nd } \\
\text { batch }\end{array}$ & $\begin{array}{c}\text { The } \\
\text { 3rd } \\
\text { batch }\end{array}$ & $\begin{array}{c}\text { The } \\
\text { 4th } \\
\text { batch }\end{array}$ & Total & Proportion \\
\hline $\begin{array}{l}1920- \\
1929\end{array}$ & 44 & 55 & 64 & 39 & 202 & $10.2 \%$ \\
\hline $\begin{array}{l}1930- \\
1939\end{array}$ & 47 & 122 & 189 & 98 & 456 & $23.0 \%$ \\
\hline $\begin{array}{l}1940- \\
1949\end{array}$ & 61 & 185 & 246 & 162 & 654 & $33.0 \%$ \\
\hline $\begin{array}{l}1950- \\
1959\end{array}$ & 52 & 84 & 130 & 99 & 365 & $18.4 \%$ \\
\hline $\begin{array}{l}1960- \\
1969\end{array}$ & 17 & 83 & 70 & 86 & 256 & $12.8 \%$ \\
\hline $\begin{array}{l}1970- \\
1979\end{array}$ & 2 & 14 & 9 & 14 & 39 & $1.9 \%$ \\
\hline $\begin{array}{l}\text { In } \\
1980 \\
\text { and } \\
\text { beyond }\end{array}$ & 0 & 0 & 0 & 0 & 0 & $0 \%$ \\
\hline \begin{tabular}{l} 
Total \\
\hline
\end{tabular} & 226 & 551 & 711 & 498 & 1986 & $100 \%$ \\
\hline
\end{tabular}

2) The gender structure was relatively stable(Table $V$ ): The gender structure was relatively stable(Table V). The ratio was stable at $7: 3$. It showed that the men have more opportunities to contact and learn intangible cultural heritage projects than women in China in history. On the other hand, it also showed that the Chinese government should create more educational opportunities to expand cultural heritage space for women.

TABLE V. The Gender Statistics TABles of NATional LeVel of CHINESE REPRESENTATIVE INHERITANCE PERSONS

\begin{tabular}{|c|c|c|c|c|c|}
\hline \multirow{2}{*}{ Batch } & \multicolumn{2}{|c|}{ Male } & \multicolumn{2}{c|}{ Female } & \multirow{2}{*}{ Total } \\
\cline { 2 - 5 } & Number & Proportion & Number & Proportion & \\
\hline The 1st batch & 184 & $81.4 \%$ & 37 & $18.6 \%$ & 226 \\
\hline The 2nd batch & 401 & $72.7 \%$ & 150 & $27.3 \%$ & 551 \\
\hline The 3rd batch & 542 & $76.2 \%$ & 169 & $23.8 \%$ & 711 \\
\hline The 4th batch & 372 & $74.6 \%$ & 126 & $25.4 \%$ & 498 \\
\hline Total & 1499 & $75.5 \%$ & 482 & $24.6 \%$ & 1986 \\
\hline
\end{tabular}

3) Ethnic composition changed significantly(Table VI): The proportion of minority intangible cultural heritage representative person gradually increased from $18.9 \%$ to $26.2 \%$ in the national level of Chinese representative inheritance perons lists. This showed that Chinese government put more attentions on the minority intangible cultural heritage protections. But on the whole, the proportion of minority intangible cultural heritage representative person was also low. 
TABLE VI. THE ETHNic STATISTICS TABLES OF NATIONAL LEVEL OF CHINESE REPRESENTATIVE INHERITANCE PERSONS

\begin{tabular}{|c|c|c|c|c|c|}
\hline \multirow{2}{*}{ Batch } & \multicolumn{2}{|c|}{ The Han Nationality } & \multicolumn{2}{|c|}{ National Minority } & \multirow{2}{*}{ Total } \\
\cline { 2 - 5 } & Number & Proportion & Number & Proportion & \\
\hline The 1st batch & 174 & $77 \%$ & 52 & $23 \%$ & 226 \\
\hline The 2nd batch & 447 & $81.1 \%$ & 104 & $18.9 \%$ & 551 \\
\hline The 3rd batch & 534 & $75.1 \%$ & 177 & $24.9 \%$ & 711 \\
\hline The 4th batch & 368 & $73.8 \%$ & 130 & $26.2 \%$ & 498 \\
\hline Total & 1523 & $76.7 \%$ & 463 & $23.3 \%$ & 1986 \\
\hline
\end{tabular}

\section{ThE TRENDS OF CHINESE INTANGIBLE CULTURAL HERITAGE REPRESENTATIVE LIST}

\section{A. Systematic Improvement of intangible cultural heritage representative list}

Intangible cultural heritage was promoted by UNESCO as a counterpart to the World Heritage that focuses mainly on tangible aspects of culture. According to the 2003 Convention for the Safeguarding of the Intangible Cultural Heritage, the intangible cultural heritage was defined as follows: Intangible cultural heritage means the practices, representations, expressions, knowledge, skills - as well as the instruments, objects, artifacts and cultural spaces associated therewith - that communities, groups and, in some cases, individuals recognize as part of their cultural heritage [7]. There have been 12 projects belong to "cultural space" class in the UNESCO representative lists of the intangible cultural heritage of humanity (Table VII).

TABLE VII. The Statistics Tables of CUltral Space Projects iN Human InTANGIBle CUltural HeRITAge RePresentative WORK List

\begin{tabular}{|c|c|c|c|}
\hline Batch & Year & Element & Member state \\
\hline \multirow{5}{*}{$\begin{array}{l}\text { The 1st } \\
\text { batch }\end{array}$} & \multirow{5}{*}{2001} & $\begin{array}{l}\text { The Cultural Space of the } \\
\text { Brotherhood of the Holy Spirit of the } \\
\text { Congos of Villa Mella }\end{array}$ & $\begin{array}{l}\text { Dominican } \\
\text { Republic }\end{array}$ \\
\hline & & The Cultural Space of Sosso-Bala & Guinea \\
\hline & & $\begin{array}{l}\text { The Cultural Space of Jemaa el-Fna } \\
\text { Square }\end{array}$ & Morocco \\
\hline & & $\begin{array}{l}\text { The Cultural Space and Oral Culture } \\
\text { of the Semeiskie }\end{array}$ & $\begin{array}{l}\text { Russian } \\
\text { Federation }\end{array}$ \\
\hline & & $\begin{array}{l}\text { The Cultural Space of the Boysun } \\
\text { District }\end{array}$ & Uzbekistan \\
\hline \multirow{2}{*}{$\begin{array}{l}\text { The 2nd } \\
\text { batch }\end{array}$} & \multirow[b]{2}{*}{2003} & The Kihnu Cultural Space & Estonia \\
\hline & & $\begin{array}{l}\text { The Cultural Space of the Yaaral and } \\
\text { Degal }\end{array}$ & Mali \\
\hline \multirow{3}{*}{$\begin{array}{l}\text { The 3rd } \\
\text { batch }\end{array}$} & \multirow{3}{*}{2005} & $\begin{array}{l}\text { The Cultural Space of Palenque de } \\
\text { San Basilio }\end{array}$ & Colombia \\
\hline & & $\begin{array}{l}\text { The Cultural Space of the Bedu in } \\
\text { Petra and Wadi Rum }\end{array}$ & Jordan \\
\hline & & The Space of Gong Culture & Viet Nam \\
\hline \multirow{2}{*}{$\begin{array}{l}\text { The 5th } \\
\text { batch }\end{array}$} & \multirow[t]{2}{*}{2009} & $\begin{array}{l}\text { The Candombe and its socio-cultural } \\
\text { space: a community practice }\end{array}$ & Uruguay \\
\hline & & Suiti cultural space in Alsunga & Latvia \\
\hline
\end{tabular}

According to the UNESCO published data sorting
From the Angle of the convention for the Safeguarding of Intangible Cultural Heritage by UNESCO, or from the intangible cultural heritage practice point by the governments all over the world, it all showed that the "cultural space" was an important element in the intangible cultural heritage system. The state council of China also issued the "the interim measures of national intangible cultural heritage representative work", which ruled the specific requirements about "cultural space" in the 3rd chapter 6 parts in the article [8].

So, the Chinese intangible cultural heritage representative list should be with the international trend as soon as possible and create the "cultural space" element as a new type in intangible cultural protection system.

\section{B. Systematic Reorganization of intangible cultural heritage representative list}

In the first paragraph of article 2, the UNESCO definition of intangible cultural heritage was oral traditions and expressions, including language as a vehicle of the intangible cultural heritage. From the above definition of UNESCO, the national language was also the 1st type of "the code table of national folk culture protection project survey manual" in China [9]. So, the language was an important component content in the UNESCO representative list of the intangible cultural heritage of humanity.

The inheritance of languages and dialects is a kind of group behaviors. But existence intangible heritage protection works have based on the individual inheritance person and project. The group protection works were a new field, which have some great operating difficulties. On the other side, many minorities gradually gave up national language with Chinese historical process of popularizing mandarin. the "national language" and "folk literature" has not been distinguished in the classification system of Chinese intangible cultural heritage. People often think that myths, legends, stories, songs, epic, proverb and long poem were the language.

So, the Chinese intangible cultural heritage representative list should be optimized on the basis of its historical and social value.

\section{ACKNOWLEDGMENT}

${ }^{1}$ major program of key research base focused on the humanities and social science of Ministry of Education: Reach on the Construction and Service of Archival Information Resources based on Public Requirement (Grant No. 2009JJD870001)

\section{REFERENCES}

[1] WANG Wen-zhang, "Overview of intangible cultural heritage. Beijin:Education science press”, PP.15, 2008. (references)

[2] HU Shun-hua, "China national folk literature and art integration books was completed”, The Yangtze river daily, page:9,2009-9-7. (references)

[3] KANG Bao-cheng, "The development of Chinese intangible cultural heritage protection(2011)”. Beijin: Social science press, PP. 6,2011. (references) 
[4] ZHOU He-ping, "We will strengthen the protection of intangible cultural heritage”. Beijin:Art critic, PP.6, 2012(2). (references)

[5] Wan Liang, “Don't let the 'intangible' utilitarian”. Beijin:Chinese opera, PP.17, 2012(06). (references)

[6] ZHOU He-ping, "We will strengthen the protection of intangible cultural heritage”. Beijin:Art critic, PP.6, 2012(2). (references)

[7] Electronic Publication: "Text of the Convention for the Safeguarding of Intangible Cultural Heritage”, (UNESCO)
http://www.unesco.org/culture/ich/index.php?lg=EN\&pg=00022 (references)

[8] Electronic Publication: "The interim measures of national intangible cultural heritage representative work", (The State Council of China) http://www.gov.cn/gongbao/content/2005/content_63227.htm

[9] Chinese National Academy of Arts, "Chinese national folk culture protection project reconnaissance work manual” Beijin:Art critic, PP.19, 2005. 